12-1-1995

\title{
Tradition and Authoritative Reasoning: A Nonfoundationalist Perspective
}

John E. Thiel

Fairfield University, jethiel@fairfield.edu

Follow this and additional works at: https://digitalcommons.fairfield.edu/religiousstudies-facultypubs

\section{Peer Reviewed}

\section{Repository Citation}

Thiel, John E., "Tradition and Authoritative Reasoning: A Nonfoundationalist Perspective" (1995). Religious Studies Faculty Publications. 37.

https://digitalcommons.fairfield.edu/religiousstudies-facultypubs/37

\section{Published Citation}

Thiel, John E. "Tradition and Authoritative Reasoning: A Nonfoundationalist Perspective." Theological Studies 56.4 (1995): 627-651.

This item has been accepted for inclusion in DigitalCommons@Fairfield by an authorized administrator of DigitalCommons@Fairfield. It is brought to you by DigitalCommons@Fairfield with permission from the rightsholder(s) and is protected by copyright and/or related rights. You are free to use this item in any way that is permitted by the copyright and related rights legislation that applies to your use. For other uses, you need to obtain permission from the rights-holder(s) directly, unless additional rights are indicated by a Creative Commons license in the record and/or on the work itself. For more information, please contact digitalcommons@fairfield.edu. 


\title{
TRADITION AND AUTHORITATIVE REASONING: A NONFOUNDATIONALIST PERSPECTIVE
}

\author{
JOHN E. THIEL
}

\section{Fairfield University, Connecticut}

\begin{abstract}
A DISTINCTIVE TRATT of Roman Catholic theology is the authority accorded to tradition as a normative source for its interpretation alongside Scripture and, at least in the modern period, experience. In the 19th and 20th centuries, theologians have come to recognize that the authority of ecclesial tradition can be reconciled with the fact of its historical development, a view that is by now an axiom of Catholic theology as well as an interpretive assumption of the magisterium. ${ }^{1}$ And yet surprisingly, little critical attention has been given to how tradition is authoritative for theology when tradition is itself developing dramatically.

In these pages I would like to reflect on this issue, first, by proposing a criterion for the tentative identification of dramatically developing doctrine, second, by considering the teachings of Humanae vitae and Inter insigniores as possible illustrations of such doctrine, and third, by examining the issues of authority and theological responsibility in relation to a shared characteristic of these doctrines, i.e. the magisterium's use of reasoning and argument in its teaching. In the fourth and fifth sections, nonfoundationalist criticism will provide a constructive resource for understanding the workings of reasoning in magisterial teaching and the expectations of such reasoning in the developing Catholic tradition.
\end{abstract}

\section{DRAMATICALLY DEVELOPING DOCTRINE: DEFINITION AND CRITERIA}

By "dramatically" developing doctrine, I mean doctrine that is developing in such a way that its current authority as the authentic teaching of the magisterium will be lost at some later moment in the life of the Church, and that exhibits signs in the present moment that this final loss has begun to take place. The authority of such doctrine in the Church's present life presents a knotty problem for all in the Church, though here our concern will focus on Catholic theologians

\footnotetext{
1 The Second Vatican Council's "Dogmatic Constitution on Divine Revelation" explicitly teaches the development of Catholic tradition (Dei verbum no. 8). Translations of the conciliar documents are from Vatican Council II: The Conciliar and Post-Conciliar Documents, ed. A. Flannery, O.P. (Northport, N.Y.: Costello, 1987). A more recent statement of the International Theological Commission, which one can assume enjoys the support of the magisterium, outlines normative principles for theological interpretation in the context of developing tradition; see On the Interpretation of Dogmas (April 21, 1990), in Origins 20 no. 1 (17 May 1994) 1-14.
} 
and their work. On the one hand, Catholic theologians affirm their interpretive responsibility to the "Word of God, whether in its written form or in the form of Tradition," i.e. the "doctrine, life, and worship" of the Church handed down "to every generation." Moreover, Catholic theologians recognize the authority of the teaching office or magisterium of the Church which has been entrusted with "the task of giving an authentic interpretation of the Word of God."2 On the other hand, as moderns, Catholic theologians recognize the fact of the development of doctrine and the role played by creative theological reflection in promulgating that development through the years. Moreover, historico-critical study has demonstrated that doctrine occasionally has developed in such a way that the authentic teaching of the magisterium in an earlier historical moment later lost authority. ${ }^{3}$ As they encounter doctrine presently and authentically taught by the magisterium, Catholic theologians sometimes find themselves judging that a doctrine will undergo development in this fashion, so that the authoritative teaching of today will not be the authoritative teaching of some tomorrow. Hence our knotty problem: How is tradition, in the midst of such development, authoritative for theology?

This knotty problem, of course, also suggests another: By what criteria does the theologian judge authentic teaching to be currently in a state of "dramatic development"? There are several ways of answering this question. An answer of wide interpretive latitude might suggest that all doctrine is developing because even the most basic teachings of tradition are always being appropriated anew in the present moment of faith. Karl Rahner expresses this sensibility in his well-known observation that the Chalcedonian decree on the person of Christ is not an end but a beginning, i.e. of interpretive meaning. ${ }^{4}$ If all doctrine remains in development in this way, then one might think that dramatic development is always at least a possibility for all doctrine. Such cannot be the case, however, for were this possibility to be realized for a doctrine as basic as the Chalcedonian dogma, the result would be the development of another tradition rather than the development of doctrine within the Catholic tradition. Clearly, then, all doctrine cannot develop dramatically, at least not without rendering the matters

\footnotetext{
${ }^{2}$ Dei verbum nos. 8, 10.

${ }^{3}$ See, e.g., John T. Noonan, Jr., "Development in Moral Doctrine," TS 54 (1993) 662-77. Noonan's examples are magisterial teachings on the moral issues of usury, marriage, slavery, and religious freedom. An example of development in a doctrine of faith leading to its loss of authority is Pius XII's exclusion of Christians not in communion with Rome from membership in the Church in the encyclical Mystici corporis Christi (no. 102), a teaching reversed in Vatican II's "Decree on Ecumenism" (Unitatis redintegratio no. 3). See John H. Wright, S.J., "That All Doubt May Be Removed," America 171 no. 3 (30 July 1994) 18-19.

${ }^{4}$ Karl Rahner, "Current Problems in Christology," in Theological Investigations 1, trans. C. Ernst (London: Darton, Longman \& Todd, 1961) 149-51.
} 
under consideration moot for want of the very tradition in which they are meaningful.

Our search for criteria for judging when doctrine is currently in a state of dramatic development might appeal to Catholic dogmatic presuppositions themselves. At the very least, one might think, doctrine that is not infallible may be capable of dramatic development. Yet this negative and minimal criterion, it turns out, is useless for making our judgment concretely because it begs the question in two respects. First, since the infallibility of doctrine expresses the infallibility of the whole Church's faith, that infallibility often does not reach the level of explicit definition, say, in the decrees of ecumenical councils and the occasional pronouncements of the extraordinary magisterium. Thus, while the assumptions of Catholic dogma seem to imply that dramatic development could only occur among noninfallible doctrines, the lack of explicit definition of infallible teaching makes it/difficult to know with precision which doctrines are infallible and which are not. This, of course, is just a more fundamental way of stating our initial problem of determining criteria for doctrine currently in a state of dramatic development. Second, reference to a doctrine's noninfallible character as a minimal criterion for judging an instance of dramatic development means little if that doctrine is taught authentically by the magisterium, presumably as the unerring faith of the whole Church. Catholic theologians are responsible to that authentic teaching and yet know that on several occasions magisterial teaching has developed dramatically. This dilemma again brings us to our problem. No facile distinction between infallible and noninfallible doctrines, then, will enable us to identify dramatically developing doctrine with any reliability.

Catholic belief in the infallibility of the Church, though, suggests another criterion that proves more reliable. According to the Second Vatican Council, the "whole body of the faithful who have an anointing that comes from the holy one ... cannot err in matters of belief." This unerring belief appears in "the supernatural appreciation of the faith (sensus fidei) of the whole people, when ... they manifest a universal consent in matters of faith or morals." The sensus fidei is not a selfsubsistent belief isolated from other dimensions of ecclesial life and practice, including the hierarchical teaching office. Indeed, the unerring sense of the faith is guided by the magisterium, relying on its teaching for the preservation of its truth. Yet, at the same time, the sense of the faith is the faith of the "People of God, . . from the bishops to the last of the faithful,"6 and so it cannot simply be reduced to the teaching of the magisterium. Magisterial teaching that has not been received in belief and practice by a wide segment of the faithful, then,

\footnotetext{
${ }^{5}$ Lumen gentium no. 12.
} 
offers a more reliable, but still incomplete, criterion for judging when doctrine is currently in a state of dramatic development.

This criterion is not without its ambiguities. Sociological findings may be helpful in locating teaching not received by the faithful, but polling results alone cannot establish the extent of doctrinal reception. In addition, there remains the theological issue of how one understands Lumen gentium's reference to "the whole body of the faithful" in which infallibility resides. Does this phrase refer to the baptized, to practitioners of the faith, or more self-referentially to those who do indeed possess the unerring sense of the faith, however difficult it may be to determine its character or their number? This question points to the inherent difficulties attending judgments about doctrinal reception. Although appeal may be made to social-scientific data in testing the reception of doctrine in the Church, one must rely finally on the sense of the faith itself in judging whether doctrine has been received by the faithful, who in turn evaluate the legitimacy of the judgment. In any case, defining the unerring faithful as those who receive all magisterial teaching in faith and practice wrongly equates the infallibility of the Church with obedience to the magisterium in any particular historical moment, and ignores both the dynamics of doctrinal development and the fact of dramatic development in the tradition. The criterion of reception, then, remains ambiguous, though by nature and not by fault. This ambiguity can be mitigated somewhat by two supplementary criteria.

A second criterion for judging current dramatic development is that the magisterium also invokes theological argument in the presentation of its teaching. The magisterial practice of supporting teaching with or actually offering teaching through theological argument can be found as early in the tradition as Leo I's fifth-century Tome on the person of $\mathrm{Christ}^{7}$ or as recently as an encyclical of Paul VI and an instruction of the Congregation for the Doctrine of the Faith to which we will soon turn for examples. ${ }^{8}$ The magisterial use of argument to convey authentic teaching is not necessarily a symptom of its noninfallible character, as the illustration of Leo's Tome, a strong textual influence on the Chalcedonian decree, testifies. But the use of theological argument in magisterial teaching is a reliable symptom that the doctrine taught is in a state of development which itself prompts the need for argument. There are three reasons for this argumentative

\footnotetext{
${ }^{7}$ Denzinger-Schönmetzer, Enchiridion Symbolorum Definitionum et Declarationum de Rebus Fidei et Morum, 33d ed. (Freiburg im Briesgau: Herder, 1966) 102-104, nos. 290-95. There is an English translation of the complete text in Christology of the Later Fathers, ed. E. Hardy (Philadelphia: Westminster, 1954) 360-70.

${ }^{8}$ Comparisons of magisterial practice across centuries yet must acknowledge the different understandings of teaching authority that have flourished in the Church; see Yves Congar, O.P., "A Semantic History of the Term 'Magisterium," " in Readings in Moral Theology No. 3: The Magisterium and Morality, ed. Charles Curran and Richard McCormick (New York: Paulist, 1982) 306-7.
} 
need to which we can refer respectively as the circumstantial, the logical, and the rhetorical. First, argument is deemed necessary because the teaching addresses changing cultural circumstances in which a simple reiteration of traditional doctrine would not suffice. Argument serves as a way of mediating traditional meaning to novel issues, problems, or situations. Second, argument is deemed necessary because this mediated teaching requires a specific and convincing application of the tradition's more basic beliefs, an application that represents a movement to doctrine more derivative, though not necessarily less authoritative. Logic (here following its traditional rules!) serves the magisterium by demonstrating the reasonableness of the application, by showing how the teaching's conclusion derives its authority from a major premise (more basic beliefs) rightly modified by its minor (changing cultural circumstances). ${ }^{9}$ Third, argument is deemed necessary because unanimity in the Church is lacking for the doctrine in question. Argument thus has the rhetorical goal of persuasion.

These first two criteria for dramatic development, when taken together-magisterial teaching that one judges not to have been widely received by the faithful and that presents its teaching through theological argument-provide good direction for determining doctrine clearly in a state of development. A third criterion must be added, however, for distinguishing development that is more likely to be dramatic. That criterion, itself a supplement to the previous two, is that the theological argument by which magisterial teaching is supported or conveyed does not prove convincing to a wide segment of Catholic theologians. If the magisterium supports or conveys its teaching by the logical application of more basic beliefs to changing circumstances in order to persuade the faithful who are disinclined toward its reception, and that argumentation does not convince a wide segment of those in the Church knowledgeable about the tradition to which it appeals and able to assess the viability of the argumentative application to present circumstances, then there is a greater likelihood that such teaching is developing dramatically than if such conditions did not prevail. Dramatic development could be encouraged in such an eventuality as theologians offered criticism of the current teaching, showing how and why the doctrinal argument advanced did not justify the teaching or offering alternative arguments that advanced another version of consistency with traditional beliefs and with the current beliefs of many in the Church.

The addition of this criterion to the first two might suggest some misunderstandings that need to be addressed quickly. First, this criterion's attention to the cogency of magisterial argument among theo-

\footnotetext{
${ }^{9}$ For an interesting discussion of logical mediation in religious doctrinal traditions, see William A. Christian, Sr., Doctrines of Religious Communities: A Philosophical Study (New Haven: Yale University, 1987) esp. 12-114.
} 
logians should not suggest that theologians speak for all the faithful. All the faithful are not concerned with arguments for the justification of belief or argument as the expression of belief, whereas theologians as a matter of professional knowledge and responsibility are. With respect to the matter of cogency in magisterial argument, they thus offer a gauge that one would not expect to find among large numbers of the faithful. Second, this criterion could seem to regard theologians as a final court of appeal in the assessment of the Church's teaching, as though the authority of theologians trumped the authority of the magisterium. As already noted, this view is contrary to Catholic belief and is not defended here. With regard to both of these concerns, this last criterion has no standing in its own right, as though magisterial teaching would need to be cogent to theologians before its enduring value for the Church could be established. Rather, this criterion is only meaningful in its relationship to the first two, all three together forming a unified complex of criteria for distinguishing likely instances of dramatic development: magisterial teaching that one judges not to have been widely received by the faithful and that presents its teaching through theological argument that does not prove convincing to a wide segment of theologians.

Our single evaluative principle attempts to identify dramatically developing doctrine by way of counterpoint to the Catholic belief that the infallibility of the Church dwells among all the faithful. It offers, then, a criteriological via negativa whose powers of identification can never constitute a proof, and no more than an indication, of doctrine in dramatic development. We would do well to think of it as a heuristic that enables us to consider our problem of the authority of such doctrine further, and we may do so by examining three examples of recent magisterial teaching.

\section{POSSIBLE EXAMPLES OF DRAMATICALLY DEVELOPING DOCTRINE}

Paul VI's encyclical Humanae vitae ("On the Regulation of Birth," 1968), and the teaching of the Congregation for the Doctrine of the Faith Inter insigniores ("On the Question of the Admission of Women to the Ministerial Priesthood," 1976), offer, I believe, examples of church teaching that fit our now single criterion of dramatic development. We can proceed by examining each in turn with regard to the three aspects of our criterion: reception, argument, and cogency.

\section{Humanae Vitae}

Humanae vitae develops by argumentation the teaching of Pius XI's encyclical Casti connubii (1930) that it is sinful to "deliberately frustrate [the] natural power and purpose" of the "conjugal act [which] is destined primarily by nature for the begetting of children."10 Paul VI's

\footnotetext{
${ }^{10}$ Pius XI, Casti connubii (December 31, 1930), in The Papal Encyclicals: 1903-1939,
} 
1968 encyclical more specifically forbids the artificial regulation of birth by direct abortion, direct sterilization, or by "any action, which either before, at the moment of, or after sexual intercourse, is specifically intended to prevent procreation"11 as contrary to the natural law and thus to the will of God. Any consideration of this teaching's reception among the faithful would need to acknowledge differences among the three forms of regulation that the teaching equally judges illicit. Abortion, for example, differs from sterilization and any other artificial means of regulating birth because it involves "the direct interruption of the generative process already begun."12 And even though many in the Church would qualify by context and circumstance the encyclical's absolute strictures against abortion, "even for therapeutic reasons," 13 few in the Church would not regard abortion as a tragic act. On the other hand, many social-scientific studies conducted in the past twenty-five years have found that a large percentage of Catholics do not practice the encyclical's proscription of artificial, preventive means of regulating births. ${ }^{14}$ Although I know of no sociological study that has made such a comparison, I think it fair to say that among those who do not practice this aspect of the encyclical's teaching few would regard the use of artificial, preventive means of birth control to constitute a tragedy of the proportions of abortion. Indeed, few who practice such forms of birth control would regard their actions as tragic at all. If this judgment is sound, then it is Humanae vitae's prohibition of artificial, preventive means of birth control in particular that has not found reception among a wide constituency of the faithful. Our further consideration of the encyclical will focus on this aspect of its teaching as a possible example of dramatically developing doctrine.

Humanae vitae presents its teaching through argument for all three reasons noted above. The encyclical begins by noting the changing historical circumstances that have prompted its teaching, among them the rapid increase in the world's population, a new social understanding of the dignity of women, and technological advances that permit the rational control of nature, including the natural laws of reproduc-

ed. C. Carlen (Raleigh, N.C.: McGrath, 1981) 391-414, no. 54. For a most thorough discussion of the history of the teaching, see John T. Noonan, Jr., Contraception: A History of Its Treatment by the Catholic Theologians and Canonists (Cambridge, Mass.: Harvard University, 1965).

${ }_{11}$ Paul VI, Humanae vitae (July 25, 1968), in The Papal Encyclicals: 1958-1981, ed. C. Carlen (Raleigh, N.C.: McGrath, 1981) 223-33, no. 14.

12 Ibid. ${ }^{13}$ Ibid.

${ }^{14}$ A typical statistic is offered in a recent Gallup poll which found that $84 \%$ of American Catholics believed they "should be allowed to practice artificial means of birth control," while 13\% believed they should not be allowed (The Gallup Poll: Public Opinion 1993 [Wilmington, Del.: Scholarly Resources, 1994] 145). A 1994 New York Times/CBS News poll found that 98\% of American Catholics 18-29 years of age practice artificial birth control, $91 \%$ of those $30-44,85 \%$ of those $45-64$, and $72 \%$ of those 65 and older (The New York Times [1 June 1994] B8). 
tion. ${ }^{15}$ One might see Paul VI's unprecedented formation of an advisory commission (and one that included lay members) to study and report to him on the issues of the encyclical as an expression of his keen sense that the Church faced circumstances novel enough to preclude a simple reiteration of the teaching of Casti connubii. To the encyclical's own list of such circumstances one might add the growing lack of the traditional teaching's reception among the faithful.

The logical argument developed in Humanae vitae to defend the prohibition of artificial, preventive forms of birth control is relatively simple. Its major premise is the basic Christian belief that all lives should be open, and faithful in action, to God's will. This major is qualified by two minor premises: God's will is inscribed in the natural law which governs procreative acts in marriage and the consummate meaning of sexual union in marriage lies in its fecundity, ${ }^{16}$ and in the inseparable connection between its "unitive" and "procreative significance," sexual union "fully retains its sense of true mutual love and its ordination to the supreme responsibility of parenthood. ..."17 Logical mediation from the major premise to the first of these two minor premises results in the encyclical's particular conclusion bearing on the intentional possibilities of the married couple pondering a reproductive decision: "From this it follows that they are not free to act as they choose in the service of transmitting life, as if it were wholly up to them to decide what is the right course to follow."18 Both minor premises are invoked to arrive at the conclusion of the Church's traditional teaching:

The Church, nevertheless, in urging men to the observance of the precepts of the natural law, which it interprets by its constant doctrine, teaches that each and every marital act must of necessity retain its intrinsic relationship to the procreation of human life. ${ }^{19}$

Artificial, preventive forms of birth control are forbidden because they destroy this intrinsic relationship between the unitive and procreative dimensions of sexual union, and thereby elevate the will of the married couple above the will of God both for the general institution of marriage and for their particular lives. Since the encyclical begins by acknowledging the "questions" 20 these matters have provoked in the Church, and moves to its final section by anticipating that "not everyone will easily accept this particular teaching,"21 it offers its argument in recognition of a lack of unanimity among the faithful on this issue, undoubtedly with persuasion as one its goals.

Demonstrating that the argument of Humanae vitae has not proved cogent to a wide segment of theologians would be a rather redundant

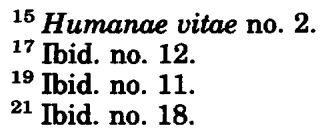

${ }^{15}$ Humanae vitae no. 2.

${ }^{17}$ Ibid. no. 12.

19 Ibid. no. 11 .

${ }^{21}$ Ibid. no. 18.

16 Ibid. no. 9.
18 Ibid. no. 10.
20 Ibid. nos. $1-3$. 
task. Indeed, the many criticisms leveled by theologians at the encyclical's reasoning stand side by side with this teaching's lack of reception as the clearest illustrations of the problem of authority in the contemporary Church. One would be hard-pressed to find a critic who challenged the encyclical's major premise-that all lives should be open, and faithful in action, to God's will. Humanae vitae's theological critics addressed instead the validity of both minor premises, and the manner of their logical relation to the major to yield the teaching's conclusion. Charles Curran, for example, criticizes the encyclical's "physicalism," its inscription of the divine will upon every conjugal act as though providence works exclusively in the teleology of biological structures. ${ }^{22}$ And when reasoning is put at issue, the encyclical's physicalist assumptions prevent its logic from distinguishing between the major and minor premises in its argument. One might even say that the argument's minor premises so eclipse its major that it becomes impossible logically to reach the reasonable conclusion, say, that a married couple could be open to the will of God by having a fecund marriage while yet at times practicing artificial contraception. Joseph Komonchak notes that the encyclical makes no attempt to justify what we have called its minor premises and so, though appearing to be an argument, is no argument at all. ${ }^{23} \mathrm{Karl}$ Rahner observes that arguments from the natural law, like Humanae vitae's, cannot prescind from the expectation of logical cogency, since reasonableness is at least one of the expectations of appeal to the natural law. And yet this cogency, he judges, is lacking in the encyclical's line of argument which does little more than state its premises. ${ }^{24}$

If space permitted, we could treat a number of other consequential criticisms of the encyclical's argument, especially those that find a conflict in moral intentionality posed by its approval of the rhythm method of birth control. Let it suffice to say that the many theologians who have criticized the teaching of Humane vitae have done so by attending to the inconsistencies they have found in the reasoning with which its teaching was promulgated.

\section{Inter Insigniores}

Inter insigniores, which presents a rationale for the Church's longestablished practice of restricting priestly ordination to men, is a teaching published on October 15, 1976 by the Congregation for the

\footnotetext{
${ }^{22}$ Charles E. Curran, "Natural Law and Contemporary Moral Theology," in Contraception: Authority and Dissent, ed. C. Curran (New York: Herder and Herder, 1969) 159-60. Cf. Charles E. Curran, Transition and Tradition in Moral Theology (Notre Dame: University of Notre Dame, 1979) 30-31.

${ }^{23}$ Joseph A. Komonchak, "Humanae Vitae and Its Reception: Ecclesiological Reflections," TS 39 (1978) 252.

${ }^{24}$ Karl Rahner, "On the Encyclical 'Humane Vitae,' " in Theological Investigations 11, trans. D. Bourke (New York: Seabury, 1974) 276-77.
} 
Doctrine of the Faith with the approval of Paul VI. Like Humanae vitae, Inter insigniores seems not to have met wide reception among the faithful. In fact, sociological evidence suggests that the acceptability of the ordination of women among Catholics in the years since the document's publication has increased substantially. For example (and one typical of North American and Western European countries), a 1977 Gallup poll found $41 \%$ of American Catholics to favor the ordination of women, a statistic that increased to $63 \%$ by $1993 .{ }^{25}$ As noted earlier, one must be wary about reducing the sensus fidei to the findings of sociologists and doubly wary about the Catholic beliefs of some nations standing as the belief of the whole Church. Yet this increase of belief in the ordination of women is telling, and enough so to judge that the teaching of the Church in question has not been widely received by the faithful. The most likely explanations for this increase are a growing awareness of injustices toward women in traditional societies, the strength of movements for the equal rights of women, and a resulting expansion of the role of women in social structures and responsibilities customarily reserved for men. One cannot completely discount, however, the influence of the document's argument itself on the increasingly wider lack of reception of the teaching among the faithful over this period of time. ${ }^{26}$

We find in Inter insigniores all three reasons, circumstantial, logical, and rhetorical, for the appeal to argument in the promulgation of magisterial teaching. The exclusive ordination of men to the priesthood is, after all, a practice that dates in some form to the first-century Church. The felt need to justify such an ancient practice stems from changing circumstances in which argument is called upon to defeat challenges to the tradition. The document's opening paragraphs identify those changing circumstances as the modern recognition of the full equality of women, the wider participation of women in the apostolate of the Church, the unqualified admission of women to pastoral office in some Protestant churches, and arguments by Catholic theologians for the ordination of women to the priesthood. ${ }^{27}$

Logical mediation is deemed necessary in Inter insigniores to bring the tradition's most basic beliefs to bear upon these changing circumstances. There are several ancillary arguments in the document that

\footnotetext{
${ }^{25}$ The 1977 Gallup poll is cited in Leonard Swidler, "Roma Locuta, Causa Finita?" in Women Priests: A Catholic Commentary on the Vatican Declaration, ed. L. Swidler and A. Swidler (New York: Paulist, 1977) 3. A 1993 Gallup poll found that 33\% of Catholic respondents "strongly agreed" and 30\% "moderately agreed" that it would be "a good thing if women were allowed to be ordained as priests" (The Gallup Poll: Public Opinion 1993 144). A 1994 New York Times/CBS News poll found that 59\% of American Catholics favored the ordination of women to the priesthood (The New York Times [1 June 1994] B8).

${ }^{26}$ See Leonard Swidler, "Roma Locuta, Causa Finita?" 3.

${ }^{27}$ Inter insigniores, "Vatican Declaration: Women in the Ministerial Priesthood," Origins 6 no. 33 (3 February 1977) 517-24, nos. 1, 3, 4.
} 
serve to refute defenses of the ordination of women based on Scripture and history. The teaching notes in passing, for example, that the "undeniable influence of prejudices unfavorable to women" in the writings of the Church Fathers had negligible effect on their pastoral practice and spiritual direction. ${ }^{28}$ The argument "from origins" continues by observing that "Jesus did not call any woman to become part of the Twelve" even though his attitude toward women did not conform to, and indeed even "deliberately and courageously broke with," the customs of his time. ${ }^{29}$ Moreover, the apostles did not consider women candidates to complete the Twelve in the Pentecost Church, even though Mary herself occupied a privileged place in their circle. Nor did Paul extend full ministerial powers to women. ${ }^{30}$ As important as these arguments "from origins" are in the document for defending the continuity of ecclesial practice against counterarguments for change, they are secondary to what we will call its argument "from representation."

Although Inter insigniores portrays its reasoning "from representation" as a matter "of clarifying [its] teaching by the analogy of faith" and not as a matter "of bringing forward a demonstrative argument,"31 the manner in which its premises lead to its conclusion seem to involve elementary deduction. The argument's major premise is the "Church's constant teaching" that "the bishop or the priest, in the exercise of his ministry, does not act in his own name, in persona propria: he represents Christ, who acts through him. ..." In the ministry, then, the priest "acts not only through the effective power conferred on him by Christ, but in persona Christi."32 This major premise is qualified by the minor premise that the incarnation of the Word "took place according to the male sex," a fact that does not imply a superiority of men over women but which nonetheless conveys a harmony in the plan of salvation revealed by God and symbolically important for the economy of revelation. ${ }^{33}$ Logical mediation yields the conclusion of the teaching that women cannot be priests because as females they could not act ministerially in persona Christi since the savior was a male. This argument's minor premise addresses contemporary cultural shifts in which feminist sensibilities would no longer assume that metaphysical conceptions like persona are intrinsically male or would insist that such conceptions transcend social (and ecclesial) bias only when they are understood in a gender-inclusive manner. The rhetoric of the argument exhibits an awareness of the claims of these sensibilities and of the need to convince those who find the traditional belief incredible-even to the point that the document anticipates and rebuffs counterarguments to the centrality it accords to the maleness of Christ.

As we found in the case of Humanae vitae, so many theologians have found the argumentation of Inter insigniores to be problematic that

28 Ibid. no. 6.

${ }^{30}$ Ibid. nos. 14-17.

32 Ibid. no. 26.
29 Ibid. no. 10.

${ }^{31}$ Ibid. no. 25.

${ }^{33}$ Ibid. nos. 28, 30. 
demonstrating its lack of cogency to a wide segment of their number becomes a redundant task. While several theological responses have criticized Inter insigniores's appeals to Scripture and the history of the early Church as legitimate warrant for its exclusion of women from priestly ordination, ${ }^{34}$ the most consequential criticism has addressed the argument "from representation." Elizabeth Johnson, among others, has criticized the crucial role of Jesus's maleness in the argument by setting its notion of representation in the orthodox Christological tradition. The Cappadocian rule of faith "what is not assumed is not saved," she notes, defined the proper understanding of human persona in the fourth-century controversy on the humanity of Christ. The rule judged wanting any notion of the humanity of Christ that excluded anything essentially human from his existence, since the excluded human dimension would not share in the hypostatic union and so not enjoy the union's saving effects. "If maleness is constitutive for the incarnation and redemption," Johnson observes, "female humanity is not assumed and therefore not saved." ${ }^{35}$ Privileging Jesus' maleness as Inter insigniores does particularizes the human notion of persona in a way that puts it at odds with the ancient rule of faith, thus destroying both the Christian notion of human person implicit in the rule and any possibility of its legitimate representation, even and perhaps especially if the object of representation is the person of Christ. Johnson concludes that an "egalitarian anthropology that holds that women and men are equally created in the image of God, and are equally one in Christ through the waters of baptism" offers a more adequate resource for considering the issue of priestly ordination. ${ }^{36}$ From the perspective of the argument's logical structure, we might understand her point to be that such an egalitarian anthropology would better shape a minor premise, and so properly qualify the major's largely uncontested expectation that the priest in ministerial duties represents the person of Christ.

Both teachings, then, appear to fit our criterion of dramatically developing doctrine, primarily because they seem not to have been widely received by the faithful and secondarily, yet importantly, because they also advance their teaching by arguments that have not

\footnotetext{
${ }^{34}$ E.g. Elizabeth Schüssler Fiorenza, "The Twelve," and "The Apostleship of Women in Early Christianity," in Women Priests 114-22, 135-40. Anne E. Carr points out that making Jesus' practice normative for the Church's practice of ordination cannot in principle sift the fact that he chose only males for the Twelve from the other traits that his choice also involved: "if the practice of Jesus were followed in all aspects, married men would have to be eligible for ordination - and only converted Jews could be ordained!" (Transforming Grace: Christian Tradition and Women's Experience [San Francisco: HarperCollins, 1988] 55).

${ }^{35}$ Elizabeth A. Johnson, She Who Is: The Mystery of God in Feminist Theological Discourse (New York: Crossroad, 1992) 153.

${ }^{36}$ Ibid.
} 
proved convincing to those in the Church professionally committed to the task of bringing understanding to faith.

\section{ARGUMENTS THAT MATTER NOT}

The reader might benefit from a reminder at this point that our efforts thus far to identify candidates for dramatically developing doctrine serve our broader purpose of considering the theological problem of such doctrine's authority. One could address this issue in a general fashion simply by reference to the large body of literature on authority in the Church, the teaching prerogatives of the magisterium, and theological responsibility that has appeared since the Second Vatican Council. I would like to pursue this question more specifically, though, by focusing on two of the features proposed here for candidates for such doctrine: the arguments offered to advance a teaching, and their cogency.

If both doctrines fit our criterion on the counts of reception, argument, and cogency, they also share another commonality with regard to the latter two aspects. Humanae vitae directly and the broader magisterial tradition of Inter insigniores indirectly subscribe to the view that finally neither their arguments nor the cogency of their arguments are consequential to the authority of their teaching. Humanae vitae expresses this position in its pastoral directives to priests:

For it is your principal duty - We are speaking especially to you who teach moral theology - to spell out clearly and completely the Church's teaching on marriage. In the performance of your ministry you must be the first to give an example of that sincere obedience, inward as well as outward, which is due to the magisterium of the Church. For, as you know, the pastors of the Church enjoy a special light of the Holy Spirit in teaching the truth. And this, rather than the arguments they put forward, is why you are bound to such obedience. $^{37}$

This same point is made indirectly in the magisterium's recent teaching on the exclusion of women from priestly ordination, not in Inter insigniores but in John Paul II's promulgation of its doctrine in Ordinatio sacerdotalis ("Apostolic Letter on Ordination and Women," May 22, 1994). This text notes the conclusions of Inter insigniores's arguments "from origins," fails to mention what many would consider to be its principal argument "from representation," reiterates the constancy of the Church's universal tradition in excluding women from priestly ordination, and concludes with the pope's particular contribution to the issue:

Wherefore, in order that all doubt may be removed regarding a matter of great importance, a matter which pertains to the church's divine constitution itself,

${ }^{37}$ Humanae vitae no. 28. 
in virtue of my ministry of confirming the brethren ... I declare that the church has no authority whatsoever to confer priestly ordination on women and that this judgment is to be definitively held by all the church's faithful. ${ }^{38}$

The status and purport of this teaching continue to be discussed in the Church. For our purposes it is important to note that the pope provides the context for his teaching in the remarks that precede the declaration quoted above. In spite of the Church's consistent teaching even to the present day, the reservation of priestly ordination to men alone, he states, "in some places ... is nonetheless considered still open to debate, or the church's judgment that women are not to be admitted to ordination is considered to have a merely disciplinary force." ${ }^{39}$ If the Apostolic Letter responds to these circumstances and offers its teaching with the intention of removing doubt in the Church, then at least one of its purposes is to close debate on this issue. This purpose, I suggest, coupled with the Letter's omission of reference to Inter insigniores's central and most debated argument, amounts to an admission that neither magisterial arguments for the exclusion of women from priestly ordination nor their cogency finally matter, since the charism of the Church's teaching office alone is the basis of its authority.

The final dispensability of argument in magisterial teachings conveyed by argument is affirmed as a general principle in the Congregation for the Doctrine of the Faith's Instruction on the Ecclesial Vocation of the Theologian (May 24, 1990). The Instruction addresses several matters concerning the responsibility of theologians to the magisterium, focusing particularly on the legitimacy and means of theological dissent from authentic teaching. One way in which theologians defend the legitimacy of dissent from "non-irreformable magisterial teaching," ${ }^{40}$ it claims, is by adopting a hermeneutical posture that regards such teaching only as one voice among many in an ongoing theological debate. "Certainly," the Instruction responds,

it is one of the theologian's tasks to give a correct interpretation to the texts of the magisterium, and to this end he employs various hermeneutical rules. Among these is the principle which affirms that magisterial teaching, by virtue of divine assistance, has a validity beyond its argumentation, which may derive at times from a particular theology. ${ }^{41}$

Right theological interpretation, then, should regard the argumentation of magisterial teaching as supplementary to its conclusion, as, on the one hand, a dimension of its presentation that theologians must strive to understand with an "intense and patient reflection"42 and yet,

${ }^{38}$ John Paul II, Ordinatio Sacerdotalis, in Origins 24 no. 4 (9 June 1994) 50-52, no. 4.

39 Ibid.

${ }^{40}$ Instruction on the Ecclesial Vocation of the Theologian, in Origins 20 no. 8 (5 July 1990) 118-26, no. 28.

${ }^{41}$ Ibid. no. 34.

42 Ibid. no. 29. 
on the other hand, a dispensable contingency should such reflection fail to yield the understanding sought.

When all sincere effort to appreciate the truth of magisterial teaching has proved fruitless, the theologian may express personal dissent only by the means of confiding privately in the magisterial authorities. One concern that might be communicated in this one valid practice of dissent is how "the arguments proposed to justify [the teaching]" are problematic. And when voiced privately, such objections can have the happy consequence of contributing "to real progress and [providing] a stimulus to the magisterium to propose the teaching of the church in greater depth and with a clearer presentation of the arguments."43 While one rejoices in any manifestation of collegiality, reconciliation, and progress in the doctrine of the faith, one cannot help but notice that the results of this private consultation extend only to magisterial argumentation and not to magisterial conclusion. As a result, argumentation becomes a gloss to conclusion-a supplement capable of clarification, modification, or even as much as separation without fear of effect upon the teaching it purports to convey. Perhaps the Instruction's expectation that an unsatisfactory resolution to private consultation is a call to the theologian "to suffer for the truth, in silence and prayer"44 is yet another expression of its view that the weighing of ecclesial argument in public would be as useless as it is scandalous since the argumentative dimension of magisterial teaching finally matters not.

Clearly the tone of our analysis suggests that something is amiss in the presumed separability of argument and conclusion in the authentic teaching of the magisterium. In the final section of this article I will try to show how the assumed contingency of magisterial argumentation bears on the theological problem of the authority of dramatically developing doctrine. At this point, however, I would state unequivocally that this problem cannot be addressed by undermining in any way the charismatic authority of the Church's teaching office, itself one of the tradition's basic beliefs. A more fruitful approach to this problem would consider how reasoning properly justifies a tradition of basic beliefs and through such justification gains cogency among faithful believers. The account of epistemic justification offered by nonfoundationalist philosophers can help to shed light on these issues.

\section{ARGUMENTS WITHOUT "FOUNDATIONS"}

While there is no definable school that represents the epistemological sensibilities of nonfoundationalism, one could at least find a family resemblance of such philosophical commitments in the tradition of American pragmatism. Building on the work of an older generation 
that includes Charles Sanders Peirce, William James, and John Dewey, contemporary pragmatists like Wilfrid Sellars, Willard Van Orman Quine, Richard Rorty, and Richard Bernstein share several common assumptions that could be described as nonfoundationalist. ${ }^{45}$ All are keenly suspicious of the Cartesian understanding of the philosophical task in which thinking is called upon to establish a "first philosophy," an architectonic of all knowledge grounded on some immediately experienced, self-certain principle that serves as "foundations" for the entire edifice of knowledge. All oppose traditional understandings of the philosophical justification of belief in which reasoning is expected to show the validity of claims to knowledge finally by appeal to indubitable "foundations" on which such claims rest. All regard the business of philosophy, at least at this moment in its history, as the criticism of Cartesianism and the formulation of more adequate accounts of knowing in which claims to knowledge are justified without appeal to foundationalist principles.

Although the nonfoundationalists frequently personify the foundationalist error by reference to Descartes, foundationalism is as old as the Platonic tradition in Western philosophy. Whether the "foundations" of knowing appear in philosophical accounts as Plato's eternal forms, Descartes's clear and distinct ideas, the givenness of sense experience for Locke, or Kant's transcendental categories of the understanding, they are esteemed by their proponents as immediately justified beliefs whose certainty justifies more derivative claims in the larger body of knowledge. Since the very purpose of "foundations" is to assure the indubitability of knowledge, or at the very least the possibility of such unquestioned certainty, foundationalists ascribe universality to whatever principle they advance as the authenticator of truth claims. As Richard Rorty observes, foundationalists seem to assume that epistemic "foundations" possess an immediate veridical élan that permeates the entire system of knowledge and "causes" whatever truth dwells among its mediate claims. ${ }^{46}$ Noninferential and indisputable, the "foundations" provide a point of departure for logical deduction or a foothold for thinking's inductive climb toward valid knowledge.

Generally speaking, one could say that nonfoundationalist criticism makes its target any variety of rationalism or empiricism that expects "foundations" for knowledge, whether in ideas or sense data, to establish the certainty of epistemic claims. Traditionally, foundationalists have been anxious at the prospect of justifying claims to knowledge if

\footnotetext{
${ }^{45}$ For the discussion that follows I have relied on the presentation of nonfoundationalist philosophies in my Nonfoundationalism, Guides to Theological Inquiry (Minneapolis: Fortress, 1994) 1-37.

${ }_{46}$ Richard Rorty, Philosophy and the Mirror of Nature (Princeton: Princeton University, 1979) 157.
} 
such foundations do not exist. Claims to knowledge, after all, can only be justified by appealing to other claims to knowledge. And if there is not an utterly basic claim, a knowledge whose immediate certainty is indubitable, then, the foundationalist fears, the justification of knowledge becomes a dizzying, infinite spiral of skepticism in which even the possibility of certainty in any instance is jeopardized. Nonfoundationalist philosophers have argued that this, in Richard Bernstein's wellknown diagnosis, "Cartesian anxiety" is a needless worry, though one prompted by strong, epistemic prejudices. ${ }^{47}$

The philosopher of science Wilfrid Sellars has argued that the foundationalist conceptualization of knowledge is energized by what he calls the "myth of the given," the "idea that there are inner episodes, whether thoughts or so-called 'immediate experiences,' to which each of us has privileged access," inner episodes furnishing "premises on which empirical knowledge rests as on a foundation." 48 While the givenness of experience is an ordinary fact of epistemic life, the imbuing of a particular dimension of experience with an authoritative givenness leads to the foundationalist schema of knowledge, in which a supposedly certain experience is called upon to provide assurances that it really cannot. There is no evidence, Sellars contends, that such a foundational, unmoved mover of knowledge exists. Indeed, as any number of the critics of foundationalism have been quick to point out, the many, and quite different, candidates for "foundations" in the history of philosophy mutually deconstruct their respective claims to immediate and obvious certainty.

Typically, nonfoundationalists argue against foundationalism by offering a view of knowledge in which its claims are relatively and mutually defined, and in which the justification of knowledge is an ongoing, revisable enterprise. Sellars, for example, points out that even the most basic report of a supposedly foundational sense experience-as in the claim "This looks red"-presupposes such a proliferating host of concepts, conditions, and circumstances that our wider network of claims to knowledge is inescapably implicated. And in this wider network, epistemic claims are mutually constituted without appeal to any truth that is immediately given. Knowledge cannot but be inferential, even if one can distinguish between more basic or more complex dimensions of its inferential character. In Sellars's judgment, this reciprocity between more basic and more complex modes of inferential knowledge does not compromise the authority of knowledge itself, but only the foundationalist authority of the myth of the given. "For empirical knowledge," he states, "like its sophisticated extension, science,

\footnotetext{
${ }^{47}$ Richard J. Bernstein, Beyond Objectivism and Relativism: Science, Hermeneutics, and Praxis (Philadelphia: University of Pennsylvania, 1983) 16-20.

48 Wilfrid Sellars, "Empiricism and the Philosophy of Mind," in Science, Perception and Reality (New York: Humanities, 1963) 140.
} 
is rational, not because it has a foundation but because it is a selfcorrecting enterprise which can put any claim in jeopardy, though not all at once."49

Like Sellars, Willard Van Orman Quine rejects any rationalist or traditionally empiricist manner of accounting for human knowledge. Philosophy, he claims, provides no " $a$ priori propaedeutic or groundwork for science." Nor does it offer some "external vantage point" from which knowledge can be constructed. Rather, philosophy is "continuous with science." $"$ Its task involves the critical examination of the formation of concepts from sensory evidence, the work of scientific construction itself. For Quine, though, the process of concept formation is inseparable from the formation of meaning in words, sentences, and the entire system of language itself. "Meaning is," Quine insists, "what it does," and what it does is place value on sensory stimulations in particular circumstances. Meaning is not a transcendental quality, a foundation on which sentences must rest in order to possess meaning, but a function of how sentences are used and through such use acquire significance. ${ }^{51}$ Meaning, then, is behaviorally layered within the complex strands of sentences that configure the "web" of belief, Quine's compelling metaphor for knowledge itself. Though a foundationalist, to pursue the metaphor, might expect the web's fixed integrity to rest upon a single strand, Quine situates the web's meaningfulness in the constant revisions to its weaving called for by the circumstances of its use. Our "statements about the external world," he maintains, "face the tribunal of sense experience not individually but only as a corporate body." 52 And the corporate body of knowledge is not only foundationless but also utterly flexible.

Sellars's and Quine's nonfoundationalist perspective on the constitution of knowledge also has implications for their understanding of epistemic justification, i.e. the task of providing arguments of sufficient warrant for claims to knowledge or beliefs. Clearly, if knowledge does not possess foundations, then neither do the arguments one offers to justify beliefs. We have already noted that the prospect of foundationless belief stirs the foundationalist's fear of an infinite justificatory regress in which even the possibility of warranted claims would be undercut. Sellars and Quine, however, do not find this prospect threatening. The arguments by which belief is justified, they hold, need not lead logically to a final grounding principle that brings the business of making justificatory arguments to closure. Both regard justificatory

49 Ibid. 170.

${ }^{50}$ W. V. Quine, "Natural Kinds," in Ontological Relativity and Other Essays (New York: Columbia University, 1969) 126-27.

${ }^{51}$ W. V. Quine, "Use and Its Place in Meaning," in Theories and Things (Cambridge, Mass.: Harvard University, 1981) 45.

${ }_{52}$ W. V. Quine, From a Logical Point of View (Cambridge, Mass.: Harvard University, 1964) 41. 
argumentation in support of claims to knowledge as an activity internal to the claims for which one argues.

For Sellars, justifications of belief fall within the scope of theorizing, the activity of explaining the beliefs we hold. Their arguments, he proposes, are best understood as self-correcting, inductive generalizations, as accounts of a rational system's reasonable coherence offered from within its own network of belief. Similarly, Quine affirms this contextual, self-referential view of justification in what has come to be known as his doctrine of holism. According to this thesis, parts of theories, including for our purposes justificatory arguments, are "not separately vulnerable to adverse observations, because it is only jointly as a theory that they imply their observable consequences." ${ }^{\text {"53 }}$ Parts of theories, in other words, including the reasoned arguments on behalf of more basic background beliefs, do not simply collapse in the face of conflicting data. Justificatory arguments so foster the basic beliefs they serve-the two utterly intertwined in the proliferating network of claims to knowledge - that contrary evidence more typically will lead to their revision than to their abandonment. Both Sellars and Quine reject what Michael Williams has called a "genetic" conception of justification in which the cogency of arguments on behalf of beliefs is assumed to be caused by the immediately certain, foundationalist principle to which they are logically joined. ${ }^{54}$ Both understand justificatory argumentation to be as foundationless, continuous, and resistant to closure as our efforts to accommodate our language to experience.

The purport of Sellars's and Quine's nonfoundationalist view on the task of justification is that what we call knowledge is its justification, itself an open-ended process of explaining-we might say arguing for - the beliefs valued in particular meaningful contexts. In the absence of "foundations," arguments are the principal means by which basic beliefs are themselves shaped, and by which their values gain cogency and thus authority. Arguments, then, are indispensable to claims to knowledge in this nonfoundationalist perspective, for the reasons they provide for beliefs not only support, relate, criticize and revise those claims but also are those claims themselves. By the same token, this nonfoundationalist understanding highlights the degree to which the contributions of argument to justification are diminished in a foundationalist understanding of knowledge. Deductive and inductive arguments in such a foundationalist schema justify a truth claim that itself requires no justification since its epistemic authority is regarded as immediate and obvious. Whatever logical authority justificatory arguments possess in a foundationalist conceptualization of

${ }^{53}$ W. V. Quine, "On Empirically Equivalent Systems of the World," Erkenntnis 9 (1975) 313.

${ }_{54}$ Michael Williams, Groundless Belief: An Essay on the Possibility of Epistemology (New Haven: Yale University, 1977) 89. 
knowledge derives finally from the "foundations" from which such arguments proceed or to which they lead in an epistemic return to origins.

In this "genetic" conception of justification, such arguments are separable from, and so in some measure supplements to, their "foundations." While the separability of "foundations" and argumentation is a constant in foundationalist argumentation, the extent of separability may vary. "Weak" versions of foundationalist argumentation may account for the logical connections between and among derivative, mediate claims to knowledge, showing, thereby, the integrity of the body of knowledge they present. Or such argumentation may confirm the purported certainty of foundationalist claims or experiences to which it has pledged logical allegiance. In comparison to a nonfoundationalist conception of justification, weak versions of foundationalist argumentation diminish the value of argumentation, though argumentation is not so separable from its "foundations" that it can be deemed indispensable. "Strong" versions of foundationalist argumentation diminish the value of argumentation even further. Resting assured that their justificatory explanations mirror the indubitability of their first principles, strong versions of foundationalism would regard their argumentation to be completely separable from, because they are utterly supplementary to, the "foundations" they serve. Here arguments, since they are but glosses to an immediately given truth, are finally dispensable and so matter little if at all. ${ }^{55}$

\section{REASONING WITH AUTHORITY}

In recent years a number of theologians have touted the value of a nonfoundationalist approach to knowledge for theological reflection. The advocates of this approach, most notably George Lindbeck, Ronald Thiemann, Stanley Hauerwas, and Charles Wood, largely have been Protestant theologians who have found the nonfoundationalist perspective helpful in refuting the apologetical use of universal theories in many modern theologies and in fostering a descriptive approach to theological interpretation consistent with a Reformation understanding of theology as scriptural exegesis. While several Catholic theologians have produced works compatible with a nonfoundationalist perspective ${ }^{56}$ this approach has often stirred Catholic suspicion, perhaps

\footnotetext{
55 The distinction introduced here between "weak" and "strong" versions of foundationalist argumentation parallels a distinction sometimes made in the philosophical literature between "weak" and "strong" foundations for knowledge. See, e.g., William P. Alston, "Has Foundationalism Been Refuted?" Philosophical Studies 29 (1976) 290-91; Ermest Sosa, "The Raft and the Pyramid: Coherence versus Foundations in the Theory of Knowledge," Midwest Studies in Philosophy 5 (1980) 14-15.

${ }_{56}$ E.g. Francis Schüssler Fiorenza, Foundational Theology: Jesus and the Church (New York: Crossroad, 1986); Nicholas Lash, Easter in Ordinary: Reflections on Human Experience and the Knowledge of God (Notre Dame: University of Notre Dame, 1990);
} 
because variations on the transcendental method advocated by influential Catholic theologians like Karl Rahner, Bernard Lonergan, and David Tracy often are cited by Protestant nonfoundationalists as examples of the foundationalist error. ${ }^{57}$ There are any number of reasons for Catholic sensibilities to be wary of the nonfoundationalist approach to knowledge. There is no reason in principle, however, to think that nonfoundationalist philosophy could not prove helpful in illuminating Catholic commitments on any number of issues, especially the proper relationship between faith and reason.

Like any philosophical stance, nonfoundationalist criticism can only be put to use legitimately in a Catholic setting if measured choices are made about which of its insights are valuable and how those insights are used to clarify beliefs that are basically Catholic. Catholic assumptions about the nature of religious reasoning, for example, could not possibly make room for the typically nonfoundationalist view that all knowledge is relative or that universality cannot be ascribed to truth claims. But to the degree that nonfoundationalist sensibilities work to expose exaggerated and finally unsustainable claims for the justification of belief, and foster an understanding of the workings of reason true to our actual beliefs and practices, they are indispensable for appreciating the conduct of right reasoning, including the reasoning invoked as authoritative in the Catholic tradition by the magisterium, theologians, and the faithful.

A nonfoundationalist perspective on the justification of belief suggests that the magisterial understanding of argumentation in its teaching is foundationalist, and even strongly so. Extraecclesial sensibilities would reach this conclusion, no doubt, because the magisterium's authoritative appeal to the charism of its office would appear to be an immediately justified belief supporting the claims issuing from the exercise of office. In this view, the charge of foundationalism amounts to the judgment that magisterial arguments cannot possess authority since the teaching office does not possess the charism that supposedly grounds its authoritative claims. But one of the advantages of a nonfoundationalist perspective is its appreciation for how claims to knowledge are contextualized, standing always in a particular framework of meaning in which commitment, practice, and belief interrelate as they serve more basic, if not foundationalist, beliefs. To the degree that the charism of the teaching office is a part of the common stock of basic Catholic beliefs, Catholic sensibilities would not find it to be comparable to the "foundations" that reason alone would criticize in

James J. Buckley, Seeking the Humanity of God: Practices, Doctrines, and Catholic Theology (Collegeville: Liturgical, 1992).

${ }^{57}$ See, e.g., George A. Lindbeck, The Nature of Doctrine: Religion and Theology in a Postliberal Age (Philadelphia: Westminster, 1984) 38; Ronald F. Thiemann, Revelation and Theology: The Gospel as Narrated Promise (Notre Dame: University of Notre Dame, 1985) 6. 
traditional epistemologies. Yet even within the circle of Catholic faith nonfoundationalist criticism suggests another respect in which magisterial argumentation is foundationalist and so, measured by the very values of the Catholic tradition, in need of revision.

On the face of it, the magisterium seems to exhibit a foundationalist regard for reasoning by skewing the proper argumentative relationship between the Catholic tradition's basic beliefs and the reasoned extension of those basic beliefs to new circumstances. In Humanae vitae, for example, natural-law reasoning is so conflated with the tradition's more basic belief in divine providence and human openness to God's workings in the world that the encyclical's natural-law arguments eclipse their major premise, as though the family lives of believers could only be open to God's will if the practice of artificial contraception were excluded. Here, magisterial reasoning, now virtually eclipsing the basic belief, takes on the character of "foundations" that immediately justify the encyclical's teaching. By making maleness an indispensable trait of the savior's humanity, Inter insigniores also conflates argument with its premise that the priestly office represents the person of Christ, creating thereby "foundations" for belief that not only immediately justify its conclusion but also do so by contradicting the tradition's basic, albeit indirect, teaching on the nature of humanity as embraced and saved by Jesus Christ. In both cases, an arguable claim is imbued with the certainty of a first principle, even though traditional beliefs more basic than those cited foundationalistically stand ready in the context of faith as viable resources for authoritative argument.

The magisterium's judgment regarding the dispensability of argumentation in its teaching further evinces a foundationalist regard for reasoning even within the setting of Catholic values, for this judgment so assumes the obvious certainty of the first principles seen to be reflected in the teaching's conclusion that the arguments by which it is reached do not share in its authority - an especially surprising stance in light of the fact that the teaching in question is presented as argument. This diremption between conclusion and argumentation-itself raised to a general principle of magisterial teaching in the Ecclesial Vocation of the Theologian-exhibits the foundationalist assumption that immediately justified beliefs "cause" the truth of mediately justified beliefs, an epistemic aetiology that in strong versions at least makes both argumentation and its cogency superfluous.

While the magisterium is inclined to explain its regard for the dispensability of argumentation by appeal to the charismatic authority of its office, a nonfoundationalist approach to the traditional knowledge it safeguards would expect that same charism to be exercised within the ongoing justification of belief in the history of faith. Within this ecclesial context, the magisterium occasionally practices the charism of authentic teaching by reiterating ancient beliefs so basic to the tradition's knowledge that they pass unquestioned from age to age. 
Frequently, though, the magisterial charism is exercised in the extension of Catholicism's basic beliefs to present circumstances that call for their guidance or that challenge customary forms of their application. Argumentation is rightly regarded not as a merely accidental dimension of this extension but as the very way in which the magisterium, in the terminology of nonfoundationalist philosophers, justifies its present teaching with regard to the tradition's ancient and basic beliefs. This, of course, does not mean that the charism of the teaching office is in thrall to reasoning whose soundness is gauged by philosophical criteria of one sort or another. The justification of the Church's belief takes place in the Catholic tradition's own authoritative network of commitments, doctrines, and practices. But the explanation of the faith that justification involves must be measured by standards of coherence and cogency that in their own terms are no less rigorous than any epistemic ideal. With regard to reasoning in magisterial teaching, this means that the charism of the teaching office is meaningfully exercised within, and not apart from, the faithful argumentation for uses to which basic beliefs might be put. When employed by the magisterium to convey its teaching, such argumentation is properly regarded as authentic and so to matter as much as a teaching's conclusion since both are normatively bound to the tradition they promulgate.

Our discussion brings us to the modest conclusion that arguments should be understood as authoritative in the Church's authentic teaching, and as inseparable from the conclusions they advance. In light of our analysis we can now consider our original problem concerning the authority of dramatically developing doctrine for Catholic theology.

Our efforts to consider this question, however tentative, must begin by noting the hermeneutical modesty with which this issue is rightly approached. The criterion for dramatically developing doctrine presented earlier in these pages offered not a sure method for identifying such doctrine but rather a heuristic for noticing possible, more likely candidates for presently authoritative Church teaching that may one day lose its authority. While reception was the most important aspect of this criterion, the supplementary aspects of argumentative presentation and cogency together mark doctrine that is developing (because argument is deemed necessary to mediate basic beliefs to present circumstances) and perhaps developing dramatically (because the very arguments conveying doctrine that has not been received by the faithful even fail to prove cogent to a wide segment of those in the Church qualified to judge the validity of argument). As noted earlier, the authority of dramatically developing doctrine is an important issue for all in the Church, though our concern here more specifically is with the authority of such doctrine for theological reflection, itself often a considerable influence on the dynamics of development in any form. And any theological judgment regarding even the possible identification of dramatically developing doctrine does well to acknowledge its own 
potential for error. After all, our two possible examples of dramatically developing doctrine have long had a place in the belief, teaching, and practice of the Church, even if not in the particular argumentative forms in which they more recently have been presented.

Only the most cavalier disregard for that tradition would judge with certainty and without ambivalence that these or any doctrines of the Church are indeed examples of dramatically developing doctrine. Nevertheless, theologians occasionally judge, properly with ambivalence and without certainty, that a particular doctrine is developing dramatically. No such judgment, though, could undermine the present status of the doctrine in question as the authentic teaching of the magisterium, for such a consequence would elevate theological assessment above the charism of the Church's teaching authority. Even as they stand in the argumentative forms in which the dramatic character of their development might be recognized, these doctrines still possess the authority that issues from any pronouncement of the ordinary magisterium as the authentic interpreter of God's revelation in Scripture and tradition. The authority of doctrine in the Catholic tradition is not measured solely by what has been or at some future time will be taught by the magisterium and received by the faithful. Such an expectation would gauge authority statically by reference to unanimity alone, ignoring the much more contested development that many authoritative teachings have had and continue to have in the Catholic tradition. Dramatically developing doctrine, then, possesses authority for Catholic theology, to say nothing of the life of the Church, as long as it continues to be taught authentically by the magisterium.

Our analysis, however, has led us to value the authority of magisterial arguments as charismatic means of promulgating the tradition's basic beliefs in present circumstances. While it is important to acknowledge the magisterial authority of these arguments, failures in their cogency and reception can only mean that their authority remains ambiguous, and so questionable, for the Church. Although apparently oxymoronic from the perspective of a foundationalist regard for the justification of ecclesial belief in which argument and conclusion are separable, the juxtaposition of authority and ambiguity is meaningful in a nonfoundationalist regard for the justification of ecclesial belief. ${ }^{58}$ In this epistemic perspective informed by Catholic commitment, argument, conclusion, and basic beliefs are inextricably bound together in the historical context of tradition in which the discernment of God's spirit at work in the Church is rarely, if ever, exhaustive. Should magisterial arguments fail to convince, then better, more coherent, traditionally faithful arguments need to be offered by those in the Church who have the ability to justify ecclesial belief. The

\footnotetext{
${ }^{58}$ For further discussion of the idea of ambiguous authority, see John E. Thiel, "Responsibility to the Spirit: Authority in the Catholic Tradition," New Theology Review 8 (1995) 53-68.
} 
Instruction on the Ecclesial Vocation of the Theologian supports this directive by encouraging theologians to contribute to the improvement of magisterial argument, though it expects theological insights to be communicated in private and assumes that such improvement will be indifferent to whatever magisterial conclusion has already been reached. A more dialogical understanding of ecclesia, and one more committed to Vatican I's teaching on the complementarity of faith and reason, ${ }^{59}$ would not fear public discussion in the Church on how its basic beliefs are logically extended to present circumstances and would be open to the possibility for such dialogue to be the very means of doctrinal development. ${ }^{60}$ The same sensibilities would hold fast to the necessary consistency between argument and conclusion in the Church's authoritative teaching, regard the cogency of such teaching as a value of tradition-bound faith, and remain open to revision in authoritative conclusion as well as in authoritative argumentation.

Reasoned argument truly informed by and demonstrating the consistency of traditional faith can never be extraneous to the authority of the Church's teaching, any more than reasoning truly in the service of faith can be foreign to the purposes of the Church. The expectation that faithful reasoning will lead to utter unanimity among the faithful would seem to be a symptom of a foundationalist understanding of its workings, as erroneous in the sphere of ecclesial knowledge as it is in any other. When conducted authoritatively, ecclesial reasoning respects the pluralism of argumentative possibilities within the tradition it holds sacred, seeks to align its expectations with what the Church has believed and continues to believe, and recognizes its own responsibility to the development of Catholic doctrine, even in the rare cases when that doctrine develops dramatically.

${ }^{59}$ Denzinger-Schönmetzer, Enchiridion 591, 592, nos. 1797, 1799.

${ }^{60}$ One convincing model for a dialogical ecclesiology is presented in Paul Lakeland, Theology and Critical Theory: The Discourse of the Church (Nashville: Abingdon, 1990). 